ISSN 1112-9867

\title{
ECONOMIC EVALUATION OF TEHRAN-NORTH FREEWAY PROJECT WITH AN EMPHASIS ON ENVIRONMENTAL HARMFUL EFFECTS
}

R. Nasrpour Parvin

Published online: 15 May 2016

\begin{abstract}
Studies on the evaluation of freeways and highways with an emphasis on the environmental impacts have been less considered in Iranian scientific and expert forums, so that most of studies have been directed at technical issues. Also, a variety of reports have been presented about Tehran-North Freeway, but since this freeway has shortened the link between the Caspian Sea and the Persian Gulf and plays a major role in the development of transit and tourism activities in the region and due to its significance, the current study examines it with an emphasis on environmental impacts. In this study, the damage model to the forest and plant species proposed in the SEEA framework by FAO organization is examined during 2006-2010. Then, the economic evaluation is made through benefit-cost method. The results indicate that there is an economic justification for Tehran-North Freeway project considering environmental impacts.
\end{abstract}

Key words- economic evaluation, Tehran-North Freeway, environmental harmful effects

Author Correspondence, e-mail: nasrpour90615177@gmail.com

doi: http://dx.doi.org/10.4314/jfas.v8i3s.263

\section{INTRODUCTION}

Development of communication channels is assumed as the symbols of development at any country, so that linking between different regions is considered as the work priority in the authorities' policies. In line with population growth, industry development and vehicle evolution, significance of transport and creation of suitable roads is necessary in different regions. Despite the significance of the establishment of communication channels for progress of communities and welfare and convenience of individuals, unfortunately if they are not designed and performed in a 
scientific and systematic way, they will have numerous negative impacts on environment. One of the negative outcomes of unsystematic road building can be destruction of environment and natural resources along the road. Yet, as specified, establishment of an easy communication channel will bring about numerous benefits from social perspectives which raise an increase in level of traffic service, reduction of accidents, reduction of travel time, saving fuel and depreciation of vehicles. For this, social benefits and costs should be examined to establish a communication channel so as to specify whether the present research has an economic justification from social perspective or not. For this purpose, the present research intends to examine economic evaluation of Tehran-North Freeway project as the largest Iran's road project which has remained incomplete with an emphasis on environmental impacts.

\section{STATEMENT OF PROBLEM}

The present research seeks to evaluate irreparable economic losses which appear due to unsystematic establishment of a freeway. Limited resources necessitate the use of the existing resources in an optimum way and the proper use of the capitals suitable way. Lack of proper use of capital not only causes the investor loses the opportunities but also causes him to face irreparable losses. To avoid these losses and use the capital in an optimum way, it requires examining any investment plan before implementation via the logical criteria and standards. If investment plans are studied and measured via a proper method in advance, but their implementation is avoided, it can avoid remaining it incomplete through essential predictions (Najahi, 2004, p. 1). Tehran-North Freeway as the largest Iran's road project is the case study in the present research, remained incomplete and found with lack of environment studies which this has raised problems. Saffari zadeh et al.(2006) in a study entitled "proposing a technicaleconomic evaluation model for evaluation of freeways and highways" deduced that it can make alignment between costs, benefits and structure of route through separate standards for cost components in road building which have been expressed in terms of important technical parameters and through the traffic relations and developed models in this context. Ibrahim Mirzaei et al.(2009) in an article entitled "economic evaluation and overview of the benefits from establishment of new transit routes" deduced that the project enjoys economic justification with discount rate(12\%) and net present value equal to 137221 million rial. Significance of this research lies on the fact that studies on evaluation of freeways and highways with an emphasis on 
environmental impacts have been less considered in Iran's scientific and expert forum, that most of studies have been associated to technical discussions on these issues. In the present research, firstly the features of the region under study and existing status of the routes under study have been introduced and then the establishment costs of any route along the freeway, benefits from the technical progress of the routes, benefits from saving during fuel, reduction of travel time, reduction of rate of accidents have been mentioned that all these have been mentioned in most of studies on evaluation of freeways and highways, and ultimately the analysis of the costs from cutting the trees in the forest in route No.4 has been made.

\section{THEORETICAL BACKGROUND}

In analysis of social benefit and cost of the projects, a general perspective existing in the community must be taken into consideration. In this analysis, the main focus has been paid on social costs and benefits rather than private costs and benefits; as a result it is obvious that such costs and benefits differ from what is considered in the private and manufacturing entities. It can say that analysis of social cost and benefit is a means to evaluate investment from social perspective and the investment in public sector, which this analysis has been largely drawn into attention in recent years especially in developing countries. Significance of this issues lies on an important role behind the public investments in these countries. In social projects, the aims such as maximization of national income, social welfare, maintenance of balance between income production and distribution, persuasion and improvement of the status of development in the region and improvement of quality of life are pursued (Samimi, 1997, p. 185).

\section{Tehran-North Freeway}

\section{The early plan of project}

Tehran-North Freeway has been being performed to meet safe, fast and cheap communication between northern and central region of the country and ease of communication with Northern Neighbours countries. The early studies on Tehran-North Freeway have started in 1974, and after the Islamic Revolution the studies on freeway route have been contested by the Department of Transportation, whereby the best plan was selected by a delegation from the Ministry of Transportation and the Management and Planning Organization of the Presidential Administration. Further, an emphasis has been put on establishment of a fast communication channel between Tehran and west of Mazandaran in the physical plan of Mazandaran and Guilan 
and a series of strategies and policies which have been issued in 1974 by the Supreme Council of Architecture and Urbanism. This freeway is a part of north-south freeway that has been the shortest route linking the Caspian Sea to the Persian Gulf with the major role in the transit of the region.

\section{The research model}

Food and Agriculture Organization (FAO) with collaboration of other countries has proposed a variety of studies on estimation of damages to forest and plant species during 1998 in form of system of integrated environment and economic accounts, represented the formula below:

In formula above, $\mathrm{t}$ represents the growth during one year and the used variables are as follows: VHt: The value of one hectare of mature forests over a period of time

P: The average value of timber

q: volumes of timber per hectare of mature forests

T: Growth of timbers in forest

i: optimum mean for the age of trees in forest

\section{The model estimation method}

In this study, linear regression model has been used for estimation. Ordinary least squares method is the most simple and common method for linear regression models. The early plan for this method which is displayed with OLS has been proposed by Friedrich gauss, German mathematician, at the 18th century. The intellectual infrastructure in the ordinary least squares method lies on this fact that the coefficients of model take the values that regression model of sample gets close to the observations. In other words, it must display the least deviation from the observations (Hashem zadeh et al. 2012, p. 80).

\section{DATA ANALYSIS}

\section{Dickey - Fuller test}

Before starting to discuss on examination, interpretation and estimation, firstly the Dickey Fuller test must be used to ensure about constant variables under study in time series. With regard to the research calculations, the results indicate that research variables are not static at level $\mathrm{I}(0)$, but they are static at level I(1) with a time pause.

\section{Overview of classical assumptions}


Ensuring about lack of collinearity between regressions or explanatory variables has been regarded as the most important feature of regression model. With regard to the results from estimation, it can say that value of VIF for each of variables has been less than 10, that research investigations indicate that there is no collinearity between explanatory variables. Concerning heterogeneity, if the variance be heterogeneous, other estimations will not be the best and will not have minimum variance. In this state, OLS is not used, because OLS gives equal weight of significance to each of observations. In this study, variance heterogeneity test using Breuch Pagan test has been made and obtained results indicate that there is no variance heterogeneity. Durbin-Watson statistics is one of the most well-known and simplest tests for detection of autocorrelation, so that Durbin-Watson statistics at detection level is greater than lower limit and less than the value in table in the regression model. Value of Durbin-Watson statistics ranges between lower and upper limit at level $5 \%$ with $\mathrm{K}=4$ and $\mathrm{n}=25$, indicating lack of positive autocorrelation; results from the study indicate that there is no autocorrelation in the model.

\section{ESTIMATION OF MODEL}

To estimate the research model which is the estimation for value of one hectare of mature forests over a period of time, three plant species in district 4 of Tehran-North Freeway with the highest forest damages regarding diversity of plants in this region and lack of access to sufficient information have been considered to collect the data. To estimate rate of growth in timber of the forest trees, the information has been collected from Forests and Rangelands Organization; further mean of value of timber price has been estimated in this way that the amount of timber of three plant species including Zarbin, Shemshad and Tous per year has been multiplied by their price during 1986-2010, that the prices have been in dollar but they have been mentioned in Rial. Ultimately, mean of value of timber price has been calculated. To calculate a volume of timer in the forest trees per year, firstly volume of timber of each tree has been calculated regarding the existing information, and then volume of wood of forest trees has been estimated using the forestry resources and type of calculation through which typing at any region has been made and volume of wood in forest trees has been estimated by taking samples from them. To estimate age of forest trees, in average statistics of age of trees Zarbin, Shemshad and Tous which exist in Iran forestry organization have been used and their mean has been estimated. By putting the obtained values in the research model which has been represented in form of SEEA and its formula as 
follow, value of one hectare of mature forests over a period of time has been estimated. Then, estimations have been made at sig $(5 \%)$ and the results below have been obtained via software STATA:

With regard to the obtained results, it can observe that all the coefficients are significant statistically. Further, the results indicate that there is a positive relationship between growth in wood of forest trees and forest value, i.e. the forests with longer history enjoy a high value. The results indicate a positive relationship between mean of price value of timber and forest value, i.e. the more price value of wood of a forest is higher, that forest value will be greater. Further, there is a direct relationship between volume of wood in forest trees and value of forest, i.e. the more forest trees are and the more volume of their wood is, value of that forest in a period of time will be greater.

\section{Economic evaluation of project and an overview on socioeconomic impacts}

Tehran-North Freeway project like any other project has costs and benefits that have existed during its implementation, which here we firstly analyze the project costs and then study the benefits of project and ultimately we examine economic evaluation of project.

\section{Estimation of costs of implementation of Tehran-North Freeway}

Costs of the present project include social, economic and technical costs.

\section{Social cost}

Social cost of project pertains to the research model which represents the environmental impacts in the region under study. With regard to the research by United States environment protection agency, value of a forest mass in maintenance of water, tourism and wood has been specified 300 million dollar, 40 million dollar and 20 million dollar, respectively. To estimate social cost in destruction of forest, value of each hectare forest per year has been multiplied by mean of prices to valued Rial per year and then mean of value of each hectare mature forest has been considered as the social cost. The social cost obtained from value of forest during 25 years equals to 2252521440000 Rial.

\section{Technical cost}

To estimate technical costs of project regarding the region under study, the information from ministry of road building and Tehran-North Freeway firm has been used. The obtained value for the technical costs of project equals to 1524800000000 Rial.

Estimation of the benefits from implementation of Tehran-North Freeway project 


\section{Reduction in fuel consumption}

Petroleum products and their consumption patterns have been constantly regarded as the important issues of country in Iran. Spending huge costs to provide oil products on one hand and paying subsidiary to provide fuel with suitable price well suited with people's income on the other hand have caused acquisition of substantial budget of currency and Rial revenues of country. Experience indicates that improvement in technical features of roads and their development cause reduction in fuel consumption. In this study, the model for reduction in fuel consumption in Electronic Toll Collection (ETC) is the proposed method, selected from Technology and Information Department of Transportation and Terminals organization. The prices released by the transportation research institute have been used to estimate the cost price as one of the factors that must be clarified. Further, the calculations in the research by Mirzaei et al.(2009) have been used for the rate of car traffic in the region under study during 24 hours and at peak and off-peak times. To estimate rate of fuel consumption in vehicles, vehicle information of automotive firms has been used. Average fuel in the vehicles has been estimated equal to 8.19; further, with regard to the prices released by transport research center, the cost price of petroleum equals to 11000 Rial that there will be681858777600 Rial reduction in fuel consumption per year regarding the estimations through implementation of the present project.

\section{Reduction of travel time}

Travel time has been regarded as one of the major economic parameters in transport, such that saving time can be the largest benefit in traffic reforms of the roads in some cases. Saving time can be used to do other activities rather than travel, so that it allows the individuals and staffs to have more efficiency for work and/or more time for their recreational activities(Ayati \& Behnoud, 2006, p. 1).

With regard to the information and statistics of Tehran-North Freeway organization, establishment of district 4 of freeway reduces 1 hour of travel time, that it can estimate the total value for the reduced hours for all the users of this road during one years based on the research by Ayati \& Behnoud(2006):

Vtotal $=(\mathrm{L} /$ speedbefore $-\mathrm{L} /$ speedafter $) \times \mathrm{ADT} \times 365 \times \mathrm{TV} \times \mathrm{N}$

Vtotal, L, speedafter, ADT, TV and N represent total value of the reduced hours for all the users of road during one year, longitude of route, average speed of vehicles before implementation of 
operations, average speed of vehicles after implementation of operations, the traffic rate of vehicles per year, value of one hour travel, average number of occupants of vehicles. According to the statistics of road organization, in average 22000 vehicles pass this region per day; further, according to the statistics of department of traffic in Alborz province, the average speed has been $40 \mathrm{~km} / \mathrm{h}$ before implementation of project and $100 \mathrm{~km} / \mathrm{h}$ in Tehran-North Freeway. Average number of occupants of vehicles has been considered 4 individuals. In the research by Ayati \& Behnoud(2006), 55.6\% of the hour wage for each Iranian person has been considered as value of one hour travel time. With regard to the statistics of Iran statistics center, revenue of Iranian household existing in 2013 is 134261402 Rial per year; with regard to the research by Mirzaei et al.(2009), if 192 hours of monthly work is considered, one hour work will have a wage about 58274 Rial that if $55.6 \%$ of it is estimated, there will be 32400 Rial, representing value of one hour of travel time. By putting the values in the formula above, the value for reduction of travel time will be about 113955336000000 Rial.

\section{Road Toll}

Since the road toll depends on the longitude of the route and speed of vehicles has no effect on cost of tolls, thus the benefit from receiving tool for the route in district 4 is obtained through the model below regarding the peak and off-peak hour:

Ctoll $=[309 \mathrm{Hp} \times($ Qp.Ln $)+(6570-309 H p) \times($ Qop.Ln $)$

Ctoll, Hp, Qp, Qop, Ln represent the benefit from paying tool for all the route, number of peak hour, number of vehicles at peak hour, number of vehicle at off-peak hour, longitude of route. With regard to the estimations, rate of benefit from toll is about 1299456000 Rial per year.

\section{Economic evaluation of project}

Now, it can control economic aspect of the project by having the costs of establishment and all the benefits from implementation of project. There are numerous methods for economic evaluation of project mentioned in the literature section. In the present research, benefit/cost method has been used.

$\mathrm{B} / \mathrm{C}=30 / 34 \quad 1$

Since the estimation of benefit-cost is greater than 1, there is economic justification for implementation of project. With regard to the results from estimation of model, review of costs and benefits from project as well as economic evaluation of the present research, it cannot reject the hypothesis under economic aspect in Tehran-North Freeway with an emphasis on 
environmental impacts. In other words, it can say that social and economic benefits of the project have been high and establishment of Tehran-North Freeway has economic justification regarding high technical and social costs of project.

\section{CONCLUSION}

Since the main purpose of this study is to examine economic evaluation of Tehran-North Freeway with an emphasis on environmental impacts, the hypothesis under economic aspect of Tehran-North Freeway with an emphasis on environmental impacts was mentioned to achieve this aim, expected to achieve this aim through testing this hypothesis. With regard to the results from the estimated model, it can be perceived that all the coefficients are significant statistically. Further, there is a positive relationship between growth of wood in forest trees and values of forest, i.e. the forests with higher history have high value. The results in table indicate a positive relationship between mean of price value of timber and value of forest, i.e. the higher the price of timber in the forest, the higher the value of that forest will be. Furthermore, there is a direct relationship between the volume of timber in forest trees and value of that forest, i.e. the more trees exist in forest, the value of that forest will be higher in a period of time. Ultimately, with regard to economic evaluation of project made through cost-benefit analysis, it can be deduced that it cannot reject the research hypothesis under economic aspect of project.

\section{SUGGESTIONS}

In this study, economic evaluation of Tehran-North Freeway was made with an emphasis on environmental impacts. A project that 35 years have passed since its establishment, but it has still remained incomplete. It seems that evaluation of projects before their implementation can be beneficial. However, this study has economic justification, with regard to the rare existing species in the region under study; it seems that it requires establishing metal bridges which have been established in most of countries to minimize damage to forests, which this requires for economic and technical evaluation. In this study, it seems that a group consisted of road building engineers, economists, social workers, lawyer, biologist, environment expert, meteorologist, geological engineer and so forth must work together before implementation of the project so far as this becomes beneficial for the next projects. This study examines economic evaluation of district 4 of 
Tehran-North Freeway, yet the entire of this project includes 4 districts that districts 1,2 and 3 have faced serious environmental damages that their overview can be interesting.

\section{REFERENCES}

Jafarisamimi, Ahmad, 1376, Basics of Engineering Economics, Mazandaran Science and Technology Publishing, edition1.

Sanati, Afsaneh, 1378, Ecological Study of Hassan Abad Branch cypress forest reserve with an emphasis on cypress trees, thesis, Islamic Azad University, North Tehran Branch

Tloei, zabiholla and Others , 1383, Tehran - North Status and Progress, Management and Planning, Office of Transportation.

Saffarzadeh, Mahmoud and Others, 1384, Technical Assessment Model - economic construction and operation of freeways and highways, Journal of Transportation, Vol1, No2.

Nekoueimehr, Mohammad and Others, 1385, The impact of road construction on deforestation in Bazoft, Journal of Forest Research and POPLAR, Journal of Transportation, Vol2, No6.

Mirzaei, Ebrahim and Others, 1388, Economic evaluation and review of the benefits of the construction of new transit (border market study projects the desire Sarbishe 78 countries), Journal of Knowledge \& Development, Vol 16, NO28.

Ahmadi, Ali and Others, 1389, Environmental degradation obstacle to sustainable development, Proceedings of the Fourth International Congress of Islamic World Geographers.

Pourbabaei, Hasan and Others, 1389, Mass structure and plant species diversity in habitats bush, the gospel Ben Gilan, Iran's journal Biology, Vol 23, NO1.

Khalili, Mohammadebrahim and Others, 1389, The effects of forest roads on the development of forest villages, Journal of Science and Technology, woody, , Vol 17, NO23.

Safari, Abolfazl, 1389, Assess the optimum density of underground transport network and estimate an optimal level of investment in forest roads, the fifth National Congress of Civil Engineering

Alikhah, Fardin, 1389, Social Impact Assessment Take the freeway Qazvin - Rasht, the tenth Conference - Research Engineering University of Guilan.

Bataman et al(1993),Extending Cost Benefit Analysis Of Uk Highway Proposal

Gardner (2013), Road In Amazon Forest, Imperial College London, 
Rahman et al (2010), Evaluation Of Environmental Emissions For Optimization Of Highway Improvement programme,Gournal Of International Development And Cooperation,Vol.16,No2. Tague \&Band (2000), Simulatin The Impact Of Road Construction And Forest Harvesting On Hydrologic Response, Gournal Of Earth Surface Processes And Landfarms, Caliskan (2013),Environmental Impact Of Forest Road Construction On Mountainous Terrain, Iranian Journal Of Environmental Health Sciences \& Engineering Yusoff \& Ishak (2005), Evaluation Of Urban Highway Environmental Noise Pollution,Journal Of Sains Malaysiana, Vol.34,No.2

\section{How to cite this article:}

Nasrpour Parvin R,. Economic evaluation of tehran-north freeway project with an emphasis on environmental harmful effects. J. Fundam. Appl. Sci., 2016, 8(3S), 814-824. 